\title{
Local Wisdom and Social Change (Roland Barthes' Semiotic Analysis in Advertisement "The Light of Aceh")
}

\author{
Rafiqah Yusna Siregar \\ Master of Communication Science, Faculty of Social and Politic Studies, \\ Universitas Sumatera Utara (USU), Indonesia \\ $\bowtie$ rafiqahyusnasiregar@gmail.com
}

Article history:

Submitted: February 23, 2021

Approved: April 30, 2021

Published: May 11, 2021

\begin{abstract}
This research focuses on answering how Acehnese local wisdom is represented and sees social changes in the community through advertising media. Using Roland Barthes' semiotic analysis to find the meaning of denotation, connotation, and myths in TV commercial "The Light of Aceh", this research employs the constructivism paradigm with qualitative methods. The denotation falls in several objects, such as a traditional house Rumoh Aceh as a place for Acehnese people to live, the customs to honor guests and eat together with them as a symbol of friendship between communities, and the Pacu Kude tradition. The connotation of the local wisdom object has been cultured and become the community's identity, then displayed in the advertisement as the result of the construction of the existing reality. This construction is interpreted as a myth that does not necessarily refer to mythology in the ordinary sense. It is traditional stories, legends, et cetera, but rather an explanation of messages with a connotative dimension. The myths found in the advertisements show the social changes taking place in Acehnese society.
\end{abstract}

Keywords: advertising; local wisdom; representation; Roland Barthes; semiotics; social changes.

Abstrak: Fokus penelitian ini adalah menjawab bagaimana kearifan lokal Aceh direpresentasikan dan melihat perubahan sosial yang terjadi di masyarakat melalui media iklan. Dengan menggunakan analisis semiotik Roland Barthes untuk menemukan makna denotasi, konotasi, dan mitos dalam iklan TV "The Light of Aceh", penelitian ini menggunakan paradigma konstruktivisme dengan metode kualitatif. Makna denotasi terdapat pada beberapa objek, seperti rumah adat Rumoh Aceh sebagai tempat tinggal masyarakat Aceh, adat istiadat untuk menghormati tamu dan makan bersama sebagai simbol persahabatan antar masyarakat, serta tradisi Pacu Kude. Objek kearifan local yang berkonotasi telah membudaya dan menjadi identitas masyarakat, kemudian ditampilkan dalam iklan tersebut sebagai hasil konstruksi dari realitas yang ada. Konstruksi ini dimaknai sebagai mitos yang tidak serta merta mengacu pada mitologi dalam pengertian biasa. Ini adalah cerita tradisional, legenda, dan sebagainya, tetapi lebih merupakan penjelasan tentang pesan dengan dimensi konotatif. Mitos yang ditemukan dalam iklan tersebut menunjukkan perubahan sosial yang terjadi pada masyarakat Aceh.

Kata kunci: iklan; kearifan lokal; perubahan social; representasi; Roland Barthes; semiotika.

P-ISSN 1907-1191 E-ISSN 2540-9204 ㄷ 2021 Author(s).

Published by LP2M INSURI Ponorogo, this is an open access journal article licensed CC-BY-SA.

DOI: 10.37680 /adabiya.v16il.715 


\section{Introduction}

Indonesia is an archipelagic country consisting of many ethnic groups and regional languages, making Indonesia a prosperous country in terms of culture. Each tribe generally has customary laws that regulate various aspects of life, ranging from issues of social relations, worship rituals, beliefs, myths to customary rules of conduct for respecting communities. Indonesia's cultural assets' richness and diversity make a significant contribution to the country to shape each region's character, uniqueness, and distinctive cultural image and play a significant role in shaping the regional image. This uniqueness contains local wisdom that might become a tourist attraction and increase local communities' creative economic growth.

One of the tourism destinations in Indonesia is Aceh. Various tourism objects and Acehnese culture are depicted in the advertisement video "The Light of Aceh". The project is one of government-sponsored tourism promotion Wonderful Indonesia's campaigns which contain local wisdom and various cultural heritages as regional cultural identities. The advertisement lasts 3 minutes 2 seconds and is the work of travel journalists from Indonesia, including Giri Prasetyo, Barry Kusuma, Michael Sjukrie, Setiadi Darmawan, and Zheldy. Broadcasted in 2016 through TV Commercial (TVC), The Light of Aceh said to reflect the oneness spirit of all Acehnese people through Islamic Sharia, which is rahmatan lil 'Alamin and as a bright light that invites goodness and prosperity, and finally benefits all parties. ${ }^{1}$

The TV Commercial "The Light of Aceh" tells of the Acehnese people's life, which is full of peace and harmony, far from conflict. The people of Aceh live and coexist with a culture whose customs are related to Islam. ${ }^{2}$ Adab, fineness and goodness of mind and character, courtesy, and morals, ${ }^{3}$ becomes norm or rule that is adhered to by the community regarding polite behavior, and it is based on religious rules. In this context, the people of Aceh live based on Islamic law rules and perform it as their local wisdom. ${ }^{4}$

Local wisdom, in general, can be interpreted as ideas of a region that are wise, full of wisdom, have good values, and are embedded and followed by members of the community. ${ }^{5}$ It can be said that local wisdom is knowledge found by local people through their experiences as they are trying to integrate it with an understanding of the area's culture and natural conditions. Local wisdom becomes an inseparable part of the culture of a society. Local wisdom is traditionally, but not necessarily, passed down from one generation to another.

${ }^{1}$ Ade Muana Husniati and Maryam Maryam, "Konstruksi Identitas Komunikasi Pemasaran Pariwisata Halal Aceh," Jurnal Jurnalisme 9, no. 1 (2020): 62-83, https://doi.org/https://doi.org/10.29103/jj.v9i1.3099.

${ }^{2}$ Arifin Zain, Syahrin Harahap, and Hasan Bakti Nasution, "The Relation of the Majority and Minority of Religious People in Aceh Singkil," Budapest International Research and Critics Institute-Journal (BIRCI-Journal), 2019, 56-65, https://doi.org/https://doi.org/10.33258/birci.v2i2.237.

${ }^{3}$ Departemen Pendidikan Nasional, Kamus besar bahasa Indonesia Pusat Bahasa : Edisi Keempat (Gramedia Pustaka Utama, 2016).

${ }^{4}$ Fachrur Rizha, Sutrisno Sutrisno, and Julia Noviani, "Communication Patterns of Religious Minority in Cultural Adaptation in Central Aceh Regency," Profetik: Jurnal Komunikasi 13, no. 2 (2020): 276-89, https://doi.org/https://doi.org/10.14421/pjk.v13i2.1889.

${ }^{5}$ Lelly Qodariah and Laely Armiyati, "Nilai-Nilai Kearifan Lokal Masyarakat Adat Kampung Naga Sebagai Alternatif Sumber Belajar," SOCIA: Jurnal Ilmu-Ilmu Sosial 10, no. 1 (2013), https://doi.org/https://doi.org/10.21831/socia.v10i1.5338; see also Triesya Melinda, Budi Rajab, and Ardini S Raksanagara, "Karodduka Tuba Marapu: Praktik Medis Pada Masyarakat Di Kampung Tarung, Sumba Barat, Nusa Tenggara Timur," Al-Adabiya: Jurnal Kebudayaan Dan Keagamaan 15, no. 01 (2020): 25-46, https://doi.org/https://doi.org/10.37680/adabiya.v15i01.235. 
To promote local wisdom and instill it properly, the Aceh Regional Government utilizes the advertising program "The Light of Aceh". Advertising is indeed one of the most recognized forms of promotional activity and is widely supported by the public. It is because the range given is extensive. Advertising is also a crucial promotional activity, especially for companies that produce goods or services for the wider community. ${ }^{6}$

A study by Wahyuningsih in 2014 entitled "Kearifan Budaya Lokal Madura Sebagai Media Persuasif (Analisis Semiotika Komunikasi Roland Barthes dalam Iklan Samsung Galaxy versi Gading dan Giselle di Pulau Madura)" gave results in the form of connotations such as the form of grateful for the Madurese community, Karapan Sapi, traditional Madurese clothing, and language which are their cultural wisdom. All elements in the advertisement are made in a persuasive form which is carried out by the producer and his creative team. Every scenes were chosen to represent the wisdom of the local Madura, then gave birth to construct the results of denotative and connotative in the advertising. The method used in this research is Roland Barthes' semiotics at two stages of significances, namely denotative, connotative, and mythical. ${ }^{7}$

Another research by Hereyah in 2012 entitled "Komodifikasi Budaya Lokal dalam Iklan: Analisis Semiotik pada Iklan Kuku Bima Energi versi Tari Sajojo" shows that the commodification of the capitalist who tried to grabbing profits from sales of products through advertising. The advertisement that was produced seemed to depict the bravery of the Papua men with the background of the Sajojo dance, which actually does not talk about bravery or fighting spirit. The Sajojo dance is basically a social dance that tells the figure of a beautiful Papua woman, lure people to take a fancy dance with her. The method used in this study is the same as the previous research, namely Roland Barthes' semiotics at two stages of significances, namely denotative, connotative, and mythical. ${ }^{8}$

Based on the two similar studies above, it can be said that both researches focus on the explanation of the representation and co-modification of local culture in advertising. Both studies are using analytics semiotics of Roland Barthes, but the analysis used only until two stage of significances (denotative, connotative and myth). Meanwhile, this research seeks to represent local wisdom in tourism advertisements with the semi-logical concept of Roland Barthes, which studies more deeply.

Advertisements with the theme of elevating the nation's culture and natural charm have started to appear recently, where many brands display art from various regions as the original identity of the Indonesian state..$^{9}$ Therefore, the Indonesian people may feel proud because there

${ }^{6}$ M A Morissan, Manajemen Media Penyiaran: Strategi Mengelola Radio \& Televisi Ed. Revisi (Prenada Media, 2018).

7 Sri Wahyuningsih, "Kearifan Budaya Lokal Madura Sebagai Media Persuasif (Analisis Semiotika Komunikasi Roland Barthes Dalam Iklan Samsung Galaxy Versi Gading Dan Giselle Di Pulau Madura)," SOSIODIDAKTIKA: Social Science Education Journal 1, no. 2 (2014): 171-80, https://doi.org/https://doi.org/10.15408/sd.v1i2.1259.

8 Yoyoh Hereyah, "Komodifikasi Budaya Lokal Dalam Iklan: Analisis Semiotik Pada Iklan Kuku Bima Energi Versi Tari Sajojo," in Prosiding Seminar Nasional Menggagas Pencitraan Berbasis Kearifan Lokal. Purwokerto: Ilmu Komunikasi FISIP Universitas Jenderal Soedirman, 2012.

${ }^{9}$ See among others Dwi Prasetyo and Denny Indrayana Setyadi, "Perancangan Film Pendek Bertema Wisata Dengan Pendekatan Storytelling Sebagai Media Promosi Wisata Pulau Bawean," Jurnal Sains Dan Seni ITS 6, no. 1 (2017): F55-61, https://doi.org/http://dx.doi.org/10.12962/j23373520.v6i1.22886; Muhammad Iqbal Harahap, "Perancangan Promosi Wisata Perkebunan Teh Rancabali Melalui Video Iklan” (Universitas Komputer Indonesia, 
are still becoming parties who take the initiative to protect cultural heritage in today's modern era. Besides, the community has begun to enter a phase where a sense of pride in this country grows. Advertisements displaying the nation's culture and wealth strengthen this cultural heritage's sense of belonging as an authentic Indonesian cultural identity.

Therefore, the researcher is interested in analyzing the "The Light of Aceh" edition of the Wonderful Indonesia advertisement videos which contains elements of local wisdom and sees social changes within the video to be examined from a semiotic point of view.

\section{Method}

The research method used in this study is qualitative, while the analysis used is semiotic analysis, where through this analysis, it can be seen the meaning contained in a text or image. This qualitative research is based on semiotic analysis using Roland Barthes' semiology to dissect the text or images. Roland Barthes' semiotic analysis looks at the reader's role and is not limited to the next level and at the context level, namely the social, cultural and economic levels. ${ }^{10}$

The object of research in this study is the advertisement video "The Light of Aceh". The local wisdom values in the advertisement will be researcher's attention, which will then be analyzed so that the meaning of denotation, connotation, and myths in the advertisement will be revealed.

In Roland Barthes' semiology concept, the meaning of denotation, connotation, and mythology in the advertisement will be examined more deeply by using five principal codes: hermeneutic code, proairetic code, symbolic code, gnomic/cultural code, and semic code. The data collection techniques used in this study are the documentation study, namely by downloading the 2016 edition of Wonderful Indonesia ad video through the YouTube site and making several screenshots of the video's important messages; and the literature study, an effort made by researchers in collecting as much relevant information as possible. Literature sources are obtained from books, journals, magazines, research results, and other suitable sources (internet, newspapers, and others).

The data analysis technique used was the Miles \& Huberman model analysis. It is explained that the data analysis technique included three activity streams, namely: (1) data reduction, which is the process of selecting data, (2) classifying, directing, and removing those deemed unnecessary and (3) organizing data in such a way as to conclude the presentation of the data. ${ }^{11}$

Finally, all data will be analyzed under the research theories to bring up local wisdom representations, social changes in advertisements, and concluding. Moreover, describing the whole object in this study based on incorporating information that has been compiled in a form deemed appropriate. It is in the presentation of the data.

2020), http://elibrary.unikom.ac.id/id/eprint/3419; and Haqqi Al Muzaqqi, "Perancangan Video Iklan Wisata Visit Kota Malang Sebagai Media Promosi” (Universitas Negeri Malang, 2018), http://repository.um.ac.id/id/eprint/14633.

10 Abdul Kodir Jailani and Rio Febriannur Rachman, "KAJIAN SEMIOTIK BUDAYA MASYARAKAT: Nilai Keislaman Dalam Tradisi Ter-Ater Di Lumajang," MUHARRIK: Jurnal Dakwah Dan Sosial 3, no. 02 (2020): 125-37, https://doi.org/https://doi.org/10.37680/muharrik.v3i02.460.

${ }_{11}$ Matthew B Miles, A Michael Huberman, and Johnny Saldaña, Qualitative Data Analysis: A Methods Sourcebook (Sage publications, 2018). 


\section{Result and Discussion}

\section{Lexia Analysis}

Lexia is an isolated section of text and has a distinctive function. A lexia could be just only consist of one or two words, groups of words, sentences and even paragraphs depending on the simplicity itself. The lexia dimension depends on the density of connotations which varies according to the moments of the text. In the process of reading the text, the lexia can be found in the form of a text or when the units are sorted in such a way that various functions are obtained at a higher level of organization. ${ }^{12}$

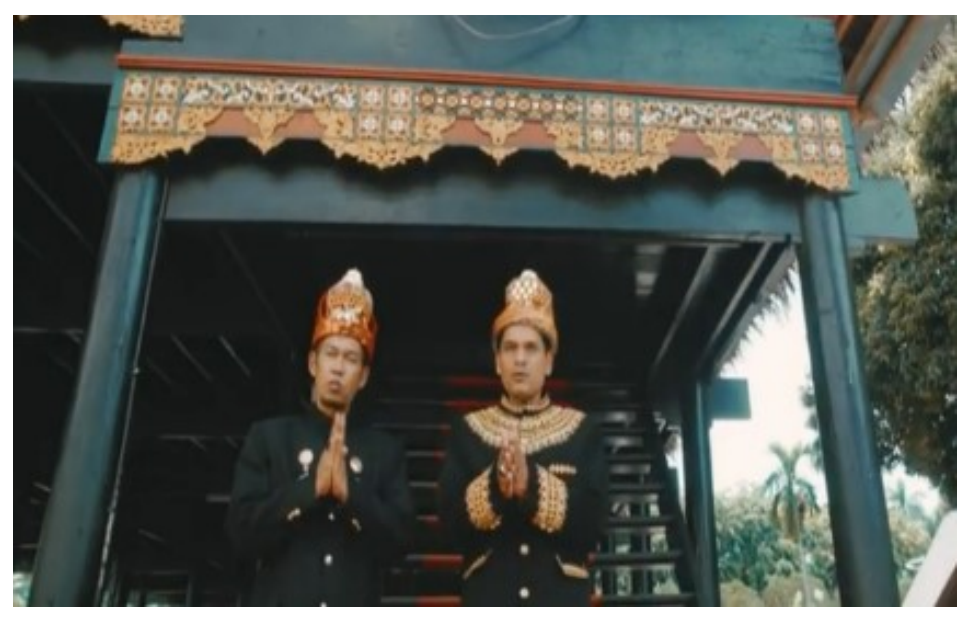

Figure 1. Traditional House and Clothes

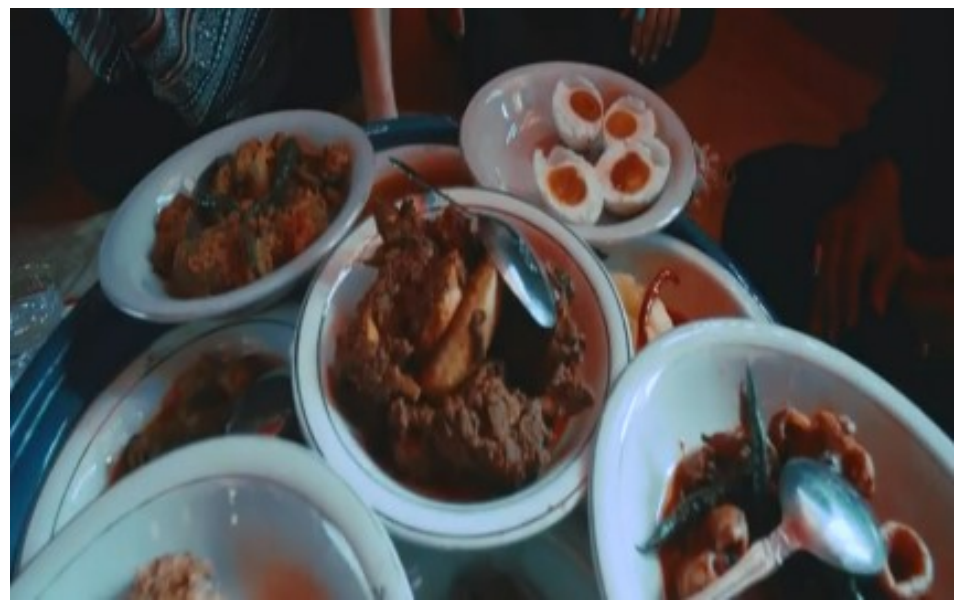

Figure 2. Traditional Food

${ }^{12}$ Ninuk Lustyantie, "Pendekatan Semiotik Model Roland Barthes Dalam Karya Sastra Prancis," in Seminar Nasional FIB UI, 2012, 1-15. 


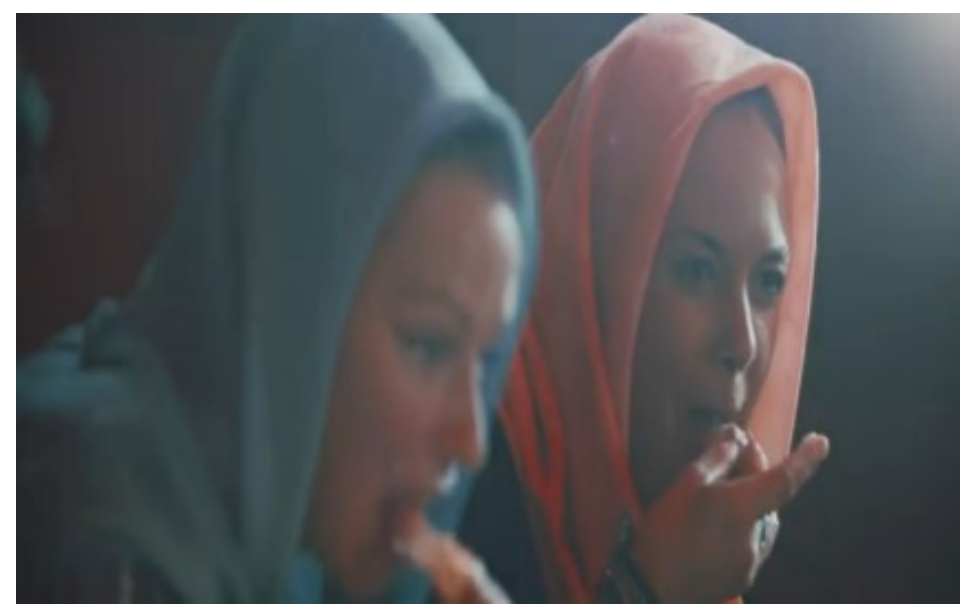

Figure 3. Eating Activities

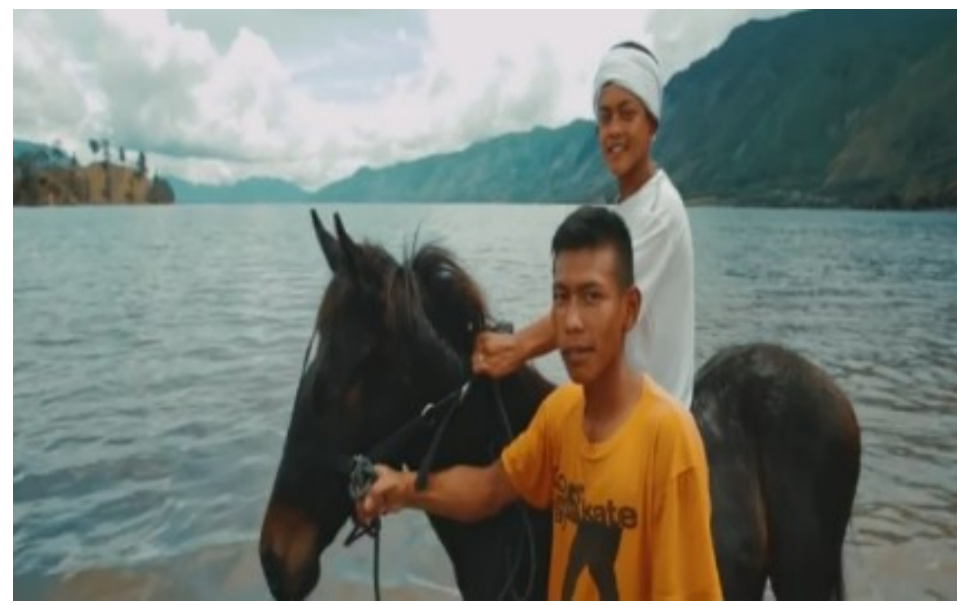

Figure 4. Рacu Kude

Figure 1 shows two men standing in front of a traditional Acehnese house wearing traditional black clothes. Figure 2 shows a variety of traditional foods. The food appears to be being served using a plate and placed on a tray. Figure 3 shows two women are eating. The two women are using their hands instead of a spoon and fork. Moreover, the two women are seen wearing scarves that covered their heads. Figure 4 shows two teenage boys, and both of them are wearing T-shirts. A boy is wearing a yellow T-shirt, and the other is wearing a white T-shirt and headband. The boy in a white T-shirt is seen sitting on a black horse. Meanwhile, the boy dressed in yellow T-shirts was seen standing, holding the rope tied to the horse. The location of this scene is on the beach.

\section{Code Reading Analysis}

In this section, five codes will be read and analyzed, namely hermeneutic code, proairetic code, symbolic code, gnomic/cultural code, and semic code. By the hermeneutic code system, some questions arise from the viewer, such as why do men in Figure 1 wear black clothes? Why does it display a traditional house? Why does Figure 2 display traditional food? Why is the food placed on the tray and floor? Why do objects or both women in Figure 3 eat with their hands without a spoon and fork? Why do both women wear scarves? Why does Figure 4 display horse riding 
activity? Why are teenage boys riding horses? Why do they ride the horse on the beach? Why are the two boys wearing T-shirts?

Furthermore, proairetic code as an explanation from the questions of the hermeneutic code might explain such an Acehnese traditional clothing for men is called Linto Baro. This traditional dress is a shirt made of woven silk, which generally has a black base color. The black color in the traditional beliefs of Aceh province is a symbol of greatness.

The traditional house of Aceh is known as Rumoh Aceh. As a cultural artifact, Rumoh Aceh can be read as a text representing society's traditions. Rumoh Aceh is a cultural artifact that functions as a place to live or live for the people of Aceh. Welcoming guests who come to visit the house has become a habit for the people of Aceh to honor guests by serving various foods, especially traditional dishes, to guests who come. Rumoh Aceh has a spacious and airy front room without any chairs and tables. Serving food on trays and being served in front of guests directly means that the host wants to honor guests who come to his house. It is so that guests do not have to queue when they want to put food on the plate. ${ }^{13}$

How to eat without using a spoon and fork provides several benefits for those who apply it, such as preventing various diseases, improving the digestive system's performance, and preventing too much food from entering the stomach. The two women are seen wearing scarves that cover their heads. It is like what has been explained previously that the province of Aceh as a region has its regional autonomy, which is different from other provinces in Indonesia, namely all regulations based on Islamic law that govern all aspects of the life of its people, including in terms of dress, especially for women. Women, especially adolescents and adults, must wear a hijab or veil to cover their bodies when doing activities outside the home. ${ }^{14}$

The horseriding activity in Figure 4 is called Pacu Kude, a competition where a jockey rides a horse to reach the finish line as quickly as possible with a predetermined course. ${ }^{15} \mathrm{Pacu}$ $K u d e$, as a routine agenda, is held every January for an entire week in commemoration of the Birthday of Bener Meriah Regency, one of the districts in the Gayo highlands. Pacu Kude is a typical event of the Gayo highland community, which is held annually. This traditional Pacu Kude is a tradition that has many positive benefits for the Gayo community besides being used as a tourism platform to build the community's economy. This tradition is also an event that can strengthen friendship and solidarity with the local community. ${ }^{16} \mathrm{Pacu}$ Kude is also held when the community has finished harvesting rice at a location near the beach.

If someone receives an award at this event, his dignity and social status will increase and be respected in the community. Prior to this Pacu Kude event, the horse owner is often willing to spend a lot of money to maintain his horse in order to win in the event. Several methods are used

\footnotetext{
${ }^{13}$ Rahil Muhammad Hasbi, "Kajian Kearifan Lokal Pada Arsitektur Tradisional Rumoh Aceh,” Vitruvian: Jurnal Arsitektur, Bangunan, Dan Lingkungan $\quad 7, \quad$ no. $\quad 1 \quad$ (2017): https://publikasi.mercubuana.ac.id/index.php/virtuvian/article/view/2717.

14 Kamaruzzaman Bustamam Ahmad, "Perempuan Aceh Dalam Perspektif Antropologi," Gender Equality: International Journal of Child and Gender Studies 1, no. 2 (2015): 37-48, https://doi.org/http://dx.doi.org/10.22373/equality.v1i2.788.

15 Mukti Ali, "Persepsi Masyarakat Gayo Tentang Pacuan Kuda Menurut Konsep Islam” (UIN Ar-Raniry Banda Aceh, 2016), https://repository.ar-raniry.ac.id/id/eprint/1602/.

16 Amalia Pintenate and Bukhari Bukhari, "Pacuan Kuda Dalam Kajian Sosiologi (Suatu Penelitian Di Kabupaten Bener Meriah)," Jurnal Ilmiah Mahasiswa Fakultas Ilmu Sosial \& Ilmu Politik 2, no. 2 (2017): 907-26, http://www.jim.unsyiah.ac.id/FISIP/article/view/2650.
} 
to keep horses looking healthy, strong, and beautiful. ${ }^{17}$ The exciting thing about the traditional Pacu Kude tradition is that the jockeys are still young, aged 10-16. The jockey's skill comes naturally by daring to ride a horse without wearing a saddle or armor. There are no special rules for choosing clothes. Jockeys wear a T-shirt with pants that are usually worn daily and without other body armor.

Symbolic code describes aspects of the fictional coding. The Aceh traditional house known as Rumoh Aceh is the identity of the Acehnese people. It is symbolically depicting Rumoh Aceh as a place to live for the people of Aceh. Apart from being a place to live for the people of Aceh, other things displayed are the community's eating manners by the teachings of the Islamic religion and the procedure for serving food in front of visiting guests.

Pacu Kude is a symbolic form in Figure 4. The symbolic form of Pacu Kude gives the meaning of harmony and solidarity of the local community. Pacu Kude is an equestrian competition so that it fosters friendship, social, economic, motivation, sportsmanship, and cultural values, which are also symbolic of this competition.

Gnomic or cultural code is a set of references or general knowledge supporting text. The depiction of a traditional house exists because the function of a traditional house is a place to live for living things, especially humans. The traditional house of an area symbolizes an identity for the community that mediates it. Each region has a different way of welcoming and honoring guests. These welcoming guests have become a local community's culture or habit and become local wisdom for the area.

Pacu Kude is part of the Gayo community's life that cannot be separated because Pacu Kude has become a social characteristic that contains solidarity values in the community, such as the value of friendship. Many people attend horse racing events to make friends with each other from various social classes. On the one hand, a social value that is a form of cooperation between communities in overcoming various problems because they already know each other is strengthened by solidarity. On the other hand, per economic value, Pacu Kude will also create economic activity because, in this arena, traders, entrepreneurs, farmers, and laborers gather to become a traditional business arena involving buying and selling activities between communities.

The value of motivation becomes an arena that can generate motivation to be creative. In the crowd, social interactions arise to exchange ideas between one another and develop motivation capable of producing works. The value of sportsmanship, in the arena of the Pacu Kude runway, a wide variety of people are gathered who will enjoy a spectacle full of sportsmanship because Pacu Kude itself is a sport that contains sportsmanship, fairness, and humility.

Semic code is connotative. Rumoh Aceh functions as a residence for Acehnese people that does not provide tables and chairs in the house's front room because of its function to welcome guests who are welcome to sit cross-legged. Pacu Kude is a tradition of equestrian racing for the Gayo community and at the same time becomes a gathering place for fellow citizens.

The existence of the myth Rumoh Aceh functions as a place for the people of Aceh to live. The function of a traditional house is a place to live for humans. Nowadays, Rumoh Aceh was almost extinct and quite hard to find. Hence, Acehnese traditional houses' existence is of great

\footnotetext{
${ }^{17}$ Pintenate and Bukhari.
} 
concern. People who are classified as well off are also almost no longer building traditional Acehnese houses. They even prefer to build modern houses because the manufacture and procurement of materials are more comfortable compared to traditional Aceh houses, where manufacture and procurement of materials are classified as brutal, and house maintenance costs are expensive. ${ }^{18}$

Each region has different ways of welcoming and honoring guests. These practices of welcoming guests have become a local community's culture or habit and become local wisdom for the area. However, in reality, there are cultural changes that significantly affect people's attitudes and behavior. Foreign cultural elements began to enter and live among children, adolescents, and even adults who changed the Acehnese people's lifestyle, in this case, eating and drinking, especially in serving food to guests.

\section{Myth and Social Changes}

There are indeed social changes in the way of lives that occur in society due to modernity and any other factors. The changes also occur in Acehnese local tradition regarding eating and drinking manners, especially in welcoming guests, because members of the community at certain times feel dissatisfied with their old life conditions. The old norms and means of living are deemed inadequate to meet the new necessities of life.

In contrast to today, eating and drinking manners already have facilities and infrastructure that support and facilitate. The people of Aceh who live today, when eating, no longer prioritize togetherness. Modern eating utensils or utensils currently complement the behavior or ethics of eating and drinking as a public attraction to its use. ${ }^{19}$

Aceh Province is an area with Islamic law regulations in it, so that all activities or culture of the Acehnese people must be based on the Islamic law including in terms of dress among the people, this is a myth in the advertisement. In fact, not all women who live reside or visit the province of Aceh wearing Muslim clothing or are more specific to the hijab. For non-Muslim women, it is permitable not to wear the hijab when doing activities outside the house. In addition, a few women who are Muslims dare not to wear hijab when they do an activity outside their home because they consider the hijab is only a "uniform" that must be worn in particular places that require wearing Muslim clothing. ${ }^{20}$

There is another myth of the tradition of horse racing for the Gayo people as a symbol of friendship between fellow citizens. This activity has also undergone many changes, namely by eliminating several methods that violate religious norms and are contrary to the Islamic law that

${ }^{18}$ Hairumini Hairumini, Dewi Liesnoor Setyowati, and Tjaturahono Budi Sanjoto, "Kearifan Lokal Rumah Tradisional Aceh Sebagai Warisan Budaya Untuk Mitigasi Bencana Gempa Dan Tsunami," Journal of Educational Social Studies 6, no. 1 (2017): 37-44, https://doi.org/https://doi.org/10.15294/jess.v6i1.16253.

${ }^{19}$ Desi Novita Sari, “Adab Makan Dan Minum Dalam Masyarakat: Kajian Sosiologi Budaya,” Electronic Theses and Dissertations (ETD) Universitas Syah Kuala, 2016, 67, https://etd.unsyiah.ac.id/index.php?p=show_detail\&id=22102.

${ }^{20}$ Muhammad Ansor, “Kita Kan Beda!': Persamaan Remaja Perempuan Muslim Dan Kristen Di Langsa, Aceh," Harmoni 13, no. 2 (2014): 37-50, https://jurnalharmoni.kemenag.go.id/index.php/harmoni/article/view/125. 
underlies the province of Aceh, contrary to Indonesia's national law and local customary norms. The most prominent case that cannot be separated from the public concern is gambling. ${ }^{21}$

Based on the problems experienced by the province of Aceh regarding local wisdom, it can be said that the local wisdom that their predecessors passed on in the past is not necessarily the same today. It means that local wisdom is considered to have positive values for the predecessors, but it is not necessarily good if it is carried out in the present. The life of the Acehnese people today is increasingly complex, seen in society's increasingly progressive mindset.

The rapid flow of information is marked by communication tools, such as the internet, which contribute to a change and cultural shift that has been the community's cultural identity. Globalization has a strong influence on changing and shifting the culture that has been embedded in society. It causes the local wisdom that the community has adopted to fade along with the times slowly. Quaritch Wales has reminded us that local wisdom is built up cumulatively, evolutionarily formed, and impermanent, can be diminished and is not always visible externally. ${ }^{22}$

The uneven and comprehensive construction of reality is contained in the advertisement "The Light of Aceh." This means that part of local wisdom is only shown in advertisements, but for the outsiders, they do not recognize and know what problems the area is experiencing. This is also in line with the main key that advertising must stimulate the attention of potential consumers to the products and services offered. Prospective consumers are led to pay attention until they feel attracted to products that provide benefits and reasons to buy and use them. ${ }^{23}$

In fact, the use of construction destination brands to existing realities often occurs. Considering there are various shifts in cultural values and social changes experienced by the local community. This situation is in line with Kotler and Pfoertsch's statement, that the brand is an immeasurable concept, often understood or considered to construct a social image as a service product and better than the actual reality. ${ }^{24} \mathrm{~A}$ destination branding is then said to be a destination concept that can construct a social image so that it looks better than the actual reality.

Indonesia has multicultural wealth, which is the local wisdom repertoire. In addition, the local wisdom of each region in Indonesia is very potential for tourism stakeholders as well as promotional producers who pay attention to cultural aspects. They can use local wisdom as their marketing strategy. In addition, it can be said that the acting parties have taken part in maintaining and preserving Indonesian culture if they display the ethnic and cultural diversity of the nation. Even though, the profits from the marketing are not evenly distributed to all levels of society.

21 Pintenate and Bukhari, "Pacuan Kuda Dalam Kajian Sosiologi (Suatu Penelitian Di Kabupaten Bener Meriah)"; see also Junisa Whusta and Mohd Din, "Upaya Penegakan Hukum Terhadap Tindak Pidana Perjudian Dalam Tradisi Pacuan Kuda (Pacu Kude) Di Aceh Tengah,” Jurnal Ilmiah Mahasiswa Bidang Hukum Pidana 3, no. 1 (2019): 178-86, http://www.jim.unsyiah.ac.id/pidana/article/view/15584.

${ }^{22}$ Ida Bagus Brata, "Kearifan Budaya Lokal Perekat Identitas Bangsa,” Jurnal Bakti Saraswati (JBS) 5, no. 1 (2016), https://jurnal.unmas.ac.id/index.php/Bakti/article/view/226.

${ }^{23}$ Agus Hermawan, Komunikasi Pemasaran (Jakarta: Penerbit Erlangga, 2013).

24 Burhan Bungin, Komunikasi Pariwisata (Tourism Communication): Pemasaran Dan Brand Destinasi (Jakarta: Prenadamedia Group, 2015). 


\section{Conclusion}

Local wisdom can provide values of goodness and prosperity and provide benefits to all parties, such as being a tourism attraction and the potential to increase the local community's creative economic growth. Even it has experienced a shift in values due to modernization or any other factors, it is still useful to be displayed in an advertisement to represent the existing reality.

\section{References}

Ahmad, Kamaruzzaman Bustamam. "Perempuan Aceh Dalam Perspektif Antropologi." Gender Equality: International Journal of Child and Gender Studies 1, no. 2 (2015): 37-48. https://doi.org/http://dx.doi.org/10.22373/equality.v1i2.788.

Ali, Mukti. "Persepsi Masyarakat Gayo Tentang Pacuan Kuda Menurut Konsep Islam." UIN ArRaniry Banda Aceh, 2016. https://repository.ar-raniry.ac.id/id/eprint/1602/.

Ansor, Muhammad. “Kita Kan Beda!': Persamaan Remaja Perempuan Muslim Dan Kristen Di Langsa, Aceh." Harmoni 13, no. 2 (2014): 37-50. https://jurnalharmoni.kemenag.go.id/index.php/harmoni/article/view/125.

Brata, Ida Bagus. "Kearifan Budaya Lokal Perekat Identitas Bangsa." Jurnal Bakti Saraswati (JBS) 5, no. 1 (2016). https://jurnal.unmas.ac.id/index.php/Bakti/article/view/226.

Bungin, Burhan. Komunikasi Pariwisata (Tourism Communication): Pemasaran Dan Brand Destinasi. Jakarta: Prenadamedia Group, 2015.

Departemen Pendidikan Nasional. Kamus besar bahasa Indonesia Pusat Bahasa: Edisi Keempat. Gramedia Pustaka Utama, 2016.

Hairumini, Hairumini, Dewi Liesnoor Setyowati, and Tjaturahono Budi Sanjoto. "Kearifan Lokal Rumah Tradisional Aceh Sebagai Warisan Budaya Untuk Mitigasi Bencana Gempa Dan Tsunami." Journal of Educational Social Studies 6, no. 1 (2017): 37-44. https://doi.org/https://doi.org/10.15294/jess.v6i1.16253.

Harahap, Muhammad Iqbal. "Perancangan Promosi Wisata Perkebunan Teh Rancabali Melalui Video Iklan.” Universitas Komputer Indonesia, 2020. http://elibrary.unikom.ac.id/id/eprint/3419.

Hasbi, Rahil Muhammad. "Kajian Kearifan Lokal Pada Arsitektur Tradisional Rumoh Aceh." Vitruvian: Jurnal Arsitektur, Bangunan, Dan Lingkungan 7, no. 1 (2017): 265311. https://publikasi.mercubuana.ac.id/index.php/virtuvian/article/view/2717.

Hereyah, Yoyoh. "Komodifikasi Budaya Lokal Dalam Iklan: Analisis Semiotik Pada Iklan Kuku Bima Energi Versi Tari Sajojo.” In Prosiding Seminar Nasional Menggagas Pencitraan Berbasis Kearifan Lokal. Purwokerto: Ilmu Komunikasi FISIP Universitas Jenderal Soedirman, 2012.

Hermawan, Agus. Komunikasi Pemasaran. Jakarta: Penerbit Erlangga, 2013.

Husniati, Ade Muana, and Maryam Maryam. "Konstruksi Identitas Komunikasi Pemasaran Pariwisata Halal Aceh.” Jurnal Jurnalisme 9, no. 1 (2020): 62-83. https://doi.org/https://doi.org/10.29103/jj.v9i1.3099.

Jailani, Abdul Kodir, and Rio Febriannur Rachman. "KAJIAN SEMIOTIK BUDAYA MASYARAKAT: Nilai Keislaman Dalam Tradisi Ter-Ater Di Lumajang." MUHARRIK: $\begin{array}{lllllll}\text { Jurnal Dakwah Dan Sosial 3, no. } 02 & \text { (2020): } & \text { 125-37. }\end{array}$ https://doi.org/https://doi.org/10.37680/muharrik.v3i02.460. 
Lustyantie, Ninuk. "Pendekatan Semiotik Model Roland Barthes Dalam Karya Sastra Prancis." In Seminar Nasional FIB UI, 1-15, 2012.

Melinda, Triesya, Budi Rajab, and Ardini S Raksanagara. "Karodduka Tuba Marapu: Praktik Medis Pada Masyarakat Di Kampung Tarung, Sumba Barat, Nusa Tenggara Timur." AlAdabiya: Jurnal Kebudayaan Dan Keagamaan 15, no. 01 (2020): 25-46. https://doi.org/https://doi.org/10.37680/adabiya.v15i01.235.

Miles, Matthew B, A Michael Huberman, and Johnny Saldaña. Qualitative Data Analysis: A Methods Sourcebook. Sage publications, 2018.

Morissan, M A. Manajemen Media Penyiaran: Strategi Mengelola Radio \& Televisi Ed. Revisi. Prenada Media, 2018.

Muzaqqi, Haqqi Al. "Perancangan Video Iklan Wisata Visit Kota Malang Sebagai Media Promosi.” Universitas Negeri Malang, 2018. http://repository.um.ac.id/id/eprint/14633.

Pintenate, Amalia, and Bukhari Bukhari. "Pacuan Kuda Dalam Kajian Sosiologi (Suatu Penelitian Di Kabupaten Bener Meriah).” Jurnal Ilmiah Mahasiswa Fakultas Ilmu Sosial \& Ilmu Politik 2, no. 2 (2017): 907-26. http://www.jim.unsyiah.ac.id/FISIP/article/view/2650.

Prasetyo, Dwi, and Denny Indrayana Setyadi. "Perancangan Film Pendek Bertema Wisata Dengan Pendekatan Storytelling Sebagai Media Promosi Wisata Pulau Bawean." Jurnal Sains Dan Seni ITS 6, no. 1 (2017): F55-61. https://doi.org/http://dx.doi.org/10.12962/j23373520.v6i1.22886.

Qodariah, Lelly, and Laely Armiyati. "Nilai-Nilai Kearifan Lokal Masyarakat Adat Kampung Naga Sebagai Alternatif Sumber Belajar.” SOCIA: Jurnal Ilmu-Ilmu Sosial 10, no. 1 (2013). https://doi.org/https://doi.org/10.21831/socia.v10i1.5338.

Rizha, Fachrur, Sutrisno Sutrisno, and Julia Noviani. "Communication Patterns of Religious Minority in Cultural Adaptation in Central Aceh Regency." Profetik: Jurnal Komunikasi 13, no. 2 (2020): 276-89. https://doi.org/https://doi.org/10.14421/pjk.v13i2.1889.

Sari, Desi Novita. “Adab Makan Dan Minum Dalam Masyarakat: Kajian Sosiologi Budaya." Electronic Theses and Dissertations (ETD) Universitas Syah Kuala, 2016, 67. https://etd.unsyiah.ac.id/index.php?p=show_detail\&id=22102.

Wahyuningsih, Sri. "Kearifan Budaya Lokal Madura Sebagai Media Persuasif (Analisis Semiotika Komunikasi Roland Barthes Dalam Iklan Samsung Galaxy Versi Gading Dan Giselle Di Pulau Madura).” SOSIO-DIDAKTIKA: Social Science Education Journal 1, no. 2 (2014): 171-80. https://doi.org/https://doi.org/10.15408/sd.v1i2.1259.

Whusta, Junisa, and Mohd Din. "Upaya Penegakan Hukum Terhadap Tindak Pidana Perjudian Dalam Tradisi Pacuan Kuda (Pacu Kude) Di Aceh Tengah." Jurnal Ilmiah Mahasiswa Bidang Hukum Pidana 3, no. 1 (2019): 178-86. http://www.jim.unsyiah.ac.id/pidana/article/view/15584.

Zain, Arifin, Syahrin Harahap, and Hasan Bakti Nasution. "The Relation of the Majority and Minority of Religious People in Aceh Singkil." Budapest International Research and $\begin{array}{llll}\text { Critics Institute-Journal } \quad \text { (BIRCI-Journal), } & \text { 56-65. }\end{array}$ https://doi.org/https://doi.org/10.33258/birci.v2i2.237. 